\title{
Antitumor activity of a monoclonal antibody against CD47 in xenograft models of human leukemia
}

\author{
SHINSUKE UNO*, YASUKO KINOSHITA*, YUMIKO AZUMA, TOSHIAKI TSUNENARI, YASUSHI YOSHIMURA, \\ SHINICHIRO IIDA, YASUFUMI KIKUCHI, HISAFUMI YAMADA-OKABE and NAOSHI FUKUSHIMA
}

Fuji-Gotemba Research Labs, Chugai Pharmaceutical Co., Ltd., Shizuoka 412-8513, Japan

Received November 14, 2006; Accepted January 23, 2007

\begin{abstract}
The ligation of CD47 induces the apoptosis of leukemic cells in a caspase-independent manner. We generated a monoclonal antibody against CD47 (mAb-MABL) that possibly induced apoptosis from the ligation of CD47 in CCRF-CEM and JOK-1 cells in vitro. To confirm whether the ligation of CD47 caused cell death in vivo, we examined the antitumor activity of $\mathrm{F}\left(\mathrm{ab}^{\prime}\right)_{2}$ of mAb-MABL in two xenograft models: The acute lymphoblastic leukemia (CCRFCEM) and the B-cell chronic lymphocytic leukemia (JOK-1) cell line. Furthermore, in order to clarify the apoptotic activity selective for the tumor cells, we examined $\mathrm{F}\left(\mathrm{ab}^{\prime}\right)_{2}$ of $\mathrm{mAb}$ MABL apoptotic effects on $\mathrm{CD} 34^{+}$hematopoietic progenitor/ stem and human endothelial cells. Male SCID mice were intravenously injected with CCRF-CEM $\left(5 \times 10^{6}\right.$ cells/mouse $)$ or JOK-1 cells $\left(5 \times 10^{6}\right.$ cells/mouse) and intraperitoneally with JOK-1 cells $\left(2 \times 10^{7}\right.$ cells/mice). After the implantation of the cells, the mice were intravenously administered the vehicle or the $\mathrm{F}\left(\mathrm{ab} \mathrm{b}^{\prime}\right)_{2}$ fragment of mAb-MABL at several doses and the length of survival was measured. $F\left(a b^{\prime}\right)_{2}$ of mAb-MABL markedly prolonged the survival of mice transplanted with CCRF-CEM and JOK-1. Significantly, $40 \%$ of the mice intraperitoneally injected with $\mathrm{JOK}-1$ cells became tumor-free when administered $\mathrm{F}\left(\mathrm{ab} \mathrm{b}^{\prime}\right)_{2}$ of mAb-MABL, whereas even a high dose of fludarabine only slightly prolonged the median survival time. On the contrary, $\left.\mathrm{F}(\mathrm{ab})_{2}\right)_{2}$ of mAb-MABL showed no apoptotic effect on $\mathrm{CD} 34^{+}$hematopoietic progenitor/stem or human endothelial cells. Thus, monoclonal antibodies that cause cell death from the ligation of CD47 could be novel therapeutic agents for incurable leukemia after further optimization such as humanization or making single chain diabodies.
\end{abstract}

Correspondence to: Dr Naoshi Fukushima, Fuji-Gotemba Research Labs, Chugai Pharmaceutical Co., Ltd. 1-135, Komakado, Gotemba, Shizuoka 412-8513, Japan

E-mail: fukushimanos@chugai-pharm.co.jp

${ }^{*}$ Contributed equally

Key words: CD47, apoptosis, B-cell chronic lymphocytic leukemia, acute lymphoblastic leukemia

\section{Introduction}

Apoptosis is a new strategy for the eradication of malignant cells. Members of the tumor necrosis factor (TNF) receptor superfamily, such as the TNF receptor, Fas, and TNF-related apoptosis ligands (TRAIL) (1-3) transduce the death signal in hematopoietic cells. In addition to the TNF receptor superfamilies, the ligation of cell surface molecules by monoclonal antibodies induces apoptosis in these cells. Such cell surface molecules include CD43 expressed in hematopoietic progenitor cells $(4,5), \mathrm{CD} 20$ in B cells and B cell lymphoma (6), CD47, CD99, and the major histocompatibility complex (MHC) class I in T cells (7-9).

CD47 is expressed on the surface of a wide variety of cells such as hematopoietic cells, keratinocytes, and the brain (10). CD47 is associated with avß3 integrin and is implicated in the modulation of integrin functions, such as cell adhesion, phagocytosis, and cellular migration events (11-14). Certain studies have demonstrated that the ligation of CD47 induces the apoptosis of $\mathrm{T}$ - and B-cell chronic lymphocytic leukemia (B-CLL) in a caspase-independent manner, and that in Tcells it leads to cytoskeleton reorganization which involves the Cdc-42/WAS protein-signaling pathway (15). Furthermore, CD47 physically interacts with BNIP3 and, upon certain signals, it induces the migration of BNIP3 to the mitochondria in order to trigger apoptosis $(16,17)$. In addition to the blood cells, cell death induced by the CD47 ligand (thrombospondin) and the anti-CD47 monoclonal antibody has been demonstrated in breast tumor cells, monocytes, dendritic cells, and fibroblasts (18-20).

$\mathrm{B}-\mathrm{CLL}$ is the most common adult hematological malignancy in western countries and is incurable even by new chemotherapeutic agents such as fludarabine and 2-chlorodeoxyadenosine (21-23). Some cytokines, such as interleukin-4 and interferon- $\gamma$ and even stromal cells, protect the B-CLL cells from apoptosis and augment the survival of malignant cells in vivo (24).

In an attempt to generate therapeutic agents for leukemia, we generated a monoclonal antibody against CD47 (mAbMABL), which induces apoptosis against leukemic cells. The $\mathrm{F}\left(\mathrm{ab}^{\prime}\right)_{2}$ fragment of mAb-MABL which caused the apoptosis of leukemic cells possibly by inducing the ligation of CD47, showed antitumor activity in vivo in the acute lymphoblastic leukemia (ALL) (CCRF-CEM) (25) and B-CLL (JOK-1) cell line $(26,27)$ xenograft models. Thus, anti-CD47 monoclonal 
antibodies could be developed as antitumor agents after further optimization such as humanization or making single chain diabodies $(28,29)$.

\section{Materials and methods}

Generation of a monoclonal antibody against CD47. L1210 cells expressing human CD47 (hCD47-L1210) were generated by the transfection of the human CD47 cDNA into mouse L1210 cells (ATCC, CCL-219) and the subsequent selection with G418. DBA/2 mice (Charles River Japan, Yokohama, Japan,) were injected intraperitoneally with $5 \times 10^{6}$ hCD47-L1210 cells. A boost injection was carried out at 4-week intervals. At the last interval, the animals were injected with $10^{8}$ hCD47-L1210 cells. The splenocytes of the mice immunized with hCD47-L1210 were fused with P3-U1 mouse myeloma cells with polyethylene glycol (Nacalai Tesque Inc., Kyoto, Japan). Hybridomas were selected by a medium containing hypoxanthine-aminopterin-thymidine (HAT) (GIBCO BRL, Rockville, MD, USA) as described previously $(30,31)$. Hybridomas were tested i) for their activity to bind to human CD47 by flow cytometry using hCD47-L1210 cells, and ii) for their ability to induce apoptosis in hCD47-L1210 cells. A hybridoma clone that produces a monoclonal antibody with a high affinity to human CD47 and strong activity to induce apoptosis in hCD47-L1210 cells was selected, and the antibody was designated as mAb-MABL.

Cells and FACS analyses. The expression of CD47 was examined using the following cells: CCRF-CEM (the human ALL cell line) (25), JOK-1 (the human B-CLL cell line) $(26,27), \mathrm{CD}^{+} 4^{+}$hematopoietic progenitor/stem and HUVEC cells. JOK-1 cells that express the B-cell marker CD19 $(26,27)$ were derived from a patient with hairy cell leukemia which was classified as CLL based on the French-AmericanBritish criteria. The JOK-1 cells were kindly provided by the Fujisaki Cell Center of the Hayashibara Institute of Biochemical Science (Okayama, Japan). These cells were cultured at $37^{\circ} \mathrm{C}$ in RPMI-1640 medium with $10 \%$ fetal bovine serum (FBS). For immunoanalysis, the cells were incubated for $1 \mathrm{~h}$ at $4{ }^{\circ} \mathrm{C}$ with $5 \mu \mathrm{g} / \mathrm{ml} \mathrm{mAb-MABL}$ or isotype-matched control mouse antibody (mouse IgG1). After washing, the cells were incubated for $1 \mathrm{~h}$ with FITC-conjugated anti-mouse IgG goat antibody (Becton-Dickinson Co., Franklin Lakes, NJ, USA). The amounts of CD47 on the surface of these cells were examined using FACSCalibur (Becton-Dickinson Co.). We also examined the expression of CD47 on CD34+ hematopoietic progenitor/stem cells. Human cord blood cells were stained with anti-CD34-PE, MABL together with anti-mouse IgG-FITC, and fluorescences were analyzed with a FACSCalibur. Cord blood cells and HUVEC were purchased from ALLCells Ltd. Liability Company and Cambrex Corporation, respectively.

Analyses of apoptosis. The apoptosis of hCD47-L1210, CCRF-CEM, JOK-1, CD34+ hematopoietic progenitor/stem and HUVEC cells by mAb-MABL was examined with Annexin-V-FLUOS (Roche Diagnostics, Basel, Switzerland) (32). The hCD47-L1210 cells were seeded at a density of
$4 \times 10^{3}$ cells $/ \mathrm{ml}$ in $2 \mathrm{ml}$ IMDM ( $10 \% \mathrm{FBS}$, Moregate, USA) containing mouse IgG $(10 \mu \mathrm{g} / \mathrm{ml})$ or mAb-MABL $(10 \mu \mathrm{g} / \mathrm{ml})$ for $72 \mathrm{~h}$ at $37^{\circ} \mathrm{C}$ under $5 \% \mathrm{CO}_{2}$. The CCRF-CEM and JOK-1 cells were seeded in a 96-well plate (round bottom) at a density of $10^{5}$ cells/100 $\mu 1$ and cultured in RPMI-1640 (10\% FBS, HyClone, Logan, UT, USA) containing $1 \mu \mathrm{g} / \mathrm{ml}$ of the $\mathrm{F}\left(\mathrm{ab}^{\prime}\right)_{2}$ fragment of mAb-MABL or $1 \mu \mathrm{g} / \mathrm{ml}$ of the $\mathrm{F}\left(\mathrm{ab}^{\prime}\right)_{2}$ fragment of the control mouse $\mathrm{IgG} 1$ (Cappel, PA, USA) for 24 or $48 \mathrm{~h}$ at $37^{\circ} \mathrm{C}$ under $5 \% \mathrm{CO}_{2}$. Human cord blood cells and HUVEC were seeded in a 96-well plate at a density of $6 \times 10^{4}$ cells $/ 100 \mu 1$ and cultured in RPMI-1640 (10\% FBS) containing $10 \mu \mathrm{g} / \mathrm{ml}$ of the $\mathrm{F}\left(\mathrm{ab}^{\prime}\right)_{2}$ fragment of $\mathrm{mAb}-\mathrm{MABL}$ or $10 \mu \mathrm{g} / \mathrm{ml}$ of the $\mathrm{F}\left(\mathrm{ab}^{\prime}\right)_{2}$ fragment of the control mouse IgG1. The cells were then centrifuged, stained with the Annexin VFITC Apoptosis Detection Kit I (Pharmingen, San Diego, CA, USA), and analyzed using FACSCalibur.

Examination of antitumor activities. The antitumor activity of the $\mathrm{F}\left(\mathrm{ab} \mathrm{b}_{2}\right)_{2}$ fragment of mAb-MABL was examined with SCID mice implanted with CCRF-CEM or JOK-1 cells. The $\mathrm{F}\left(\mathrm{ab}^{\prime}\right)_{2}$ fragment of mAb-MABL was generated by digesting the mAb-MABL with pepsin (Sigma Chemical Co., St Louis, MO, USA) and the subsequent removal of whole IgG by protein A column chromatography. Male SCID mice were intravenously injected with CCRF-CEM $\left(5 \times 10^{6}\right.$ cells/mouse) or JOK-1 cells $\left(5 \times 10^{6}\right.$ cells/mouse).

SCID mice carrying CCRF-CEM (derived from ALL) were intravenously administered the vehicle (PBS) or the $\mathrm{F}(\mathrm{ab})_{2}$ fragment of mAb-MABL at a dose of 0,50 , and $200 \mu \mathrm{g} /$ mouse twice a day (7 mice/each group) on days 3,4 , and 5 post tumor implantation.

SCID mice carrying JOK-1 cells (derived from B-CLL) were intravenously administered the vehicle (PBS) or the $\mathrm{F}\left(\mathrm{ab}^{\prime}\right)_{2}$ fragment of mAb-MABL at a dose of 1 or $5 \mathrm{mg} / \mathrm{kg}$ twice a day ( 7 mice/each group) on days 3, 4, and 5 post tumor implantation. Fludarabine was also administered intravenously at $135 \mathrm{mg} / \mathrm{kg}$ twice a day for 10 days (from day 3 to 7 and from day 10 to 14) after tumor implantation. In separate experiments, mice were intraperitoneally injected with JOK-1 cells $\left(2 \times 10^{7}\right.$ cells/mice $)$, and they were intravenously administered the vehicle (PBS) or the $\mathrm{F}\left(\mathrm{ab}^{\prime}\right)_{2}$ fragment of mAb-MABL at $1 \mathrm{mg} / \mathrm{kg}$ twice a day $(7 \mathrm{mice} /$ each group) on the first 5 days after the tumor implantation. In this study, fludarabine was administered intraperitoneally at a dose of $200 \mathrm{mg} / \mathrm{kg}$ twice a day for 10 days (from day 1 to 5 and from day 15 to 19) after tumor implantation.

Seven- or eight-week-old male SCID mice were purchased from CLEA Japan Inc. (Tokyo, Japan) and kept under specific pathogen-free conditions during the experimental period. The animals used for the experiments were treated in accordance with the guidelines established by Chugai Pharmaceuticals on the ethical care, handling, and termination of animals.

Statistical analysis. Statistical analysis was performed using the SAS system version 6.12. The Wilcoxon test was used to compare the survival between the mAb-MABL-treated group and the vehicle control group. Differences with a p-value $<0.05$ between the two groups were considered significant. 
Control F(ab')
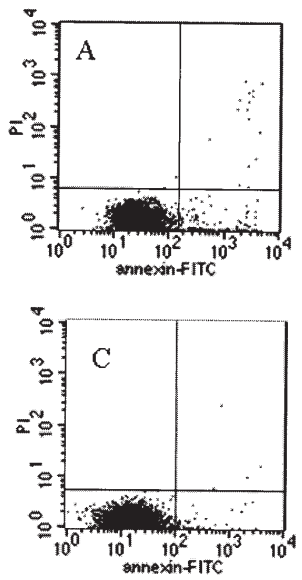

$\mathbf{F}(\mathbf{a b})_{2}$ mAb-MABL
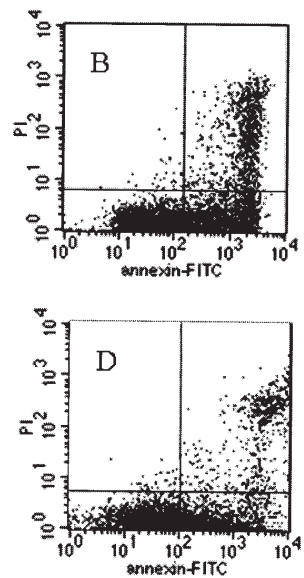

Figure 1. Induction of apoptosis by $\mathrm{F}\left(\mathrm{ab}^{\prime}\right)_{2}$ of mAb-MABL in CCRF-CEM and JOK-1 cells. The CCRF-CEM (A and B) and JOK-1 (C and D) cells were seeded in a 96-well plate (round bottom) at a density of $10^{5}$ cells $/ 100 \mu 1$ and cultured in a medium containing $1 \mu \mathrm{g} / \mathrm{ml} \mathrm{F}\left(\mathrm{ab}^{\prime}\right)_{2}$ of the control mouse IgG1 (A and C) or $1 \mu \mathrm{g} / \mathrm{ml} \mathrm{F}\left(\mathrm{ab}^{\prime}\right)_{2}$ of mAb-MABL (B and D) for 24 or $48 \mathrm{~h}$. The cells were then stained with Annexin V-FITC and PI and analyzed by FACS.

A)
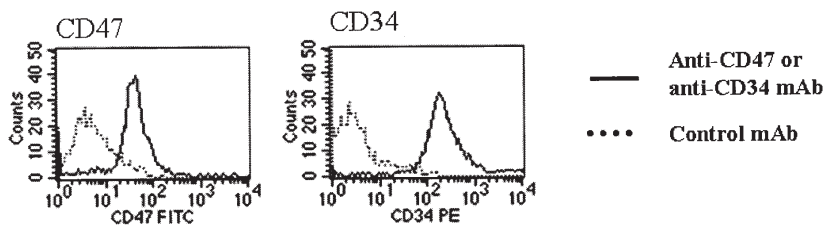

B)
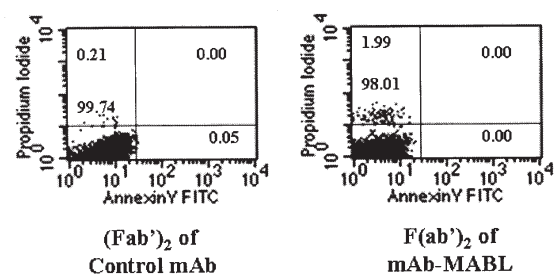

Figure 2. The expression of CD47 and CD34 (A) and cell death by F(ab') of mAb-MABL (B) in hematopoietic stem/progenitor cells. (A) Cord blood cells were stained with anti-CD34-PE, MABL (anti-CD47) together with anti-mouse IgG-FITC, and fluorescences were analyzed with a FACSCalibur. (B) Cells $\left(6 \times 10^{4}\right)$ per well of cord blood cells on a 96-well plate were cultured in the presence and absence of $10 \mu \mathrm{g} / \mathrm{ml}$ of the $\mathrm{F}\left(\mathrm{ab}^{\prime}\right)_{2}$ fragment of mAb-MABL or $10 \mu \mathrm{g} / \mathrm{ml}$ of the $\mathrm{F}\left(\mathrm{ab}^{\prime}\right)_{2}$ fragment of the control mouse IgG1. After incubation at $37^{\circ} \mathrm{C}$ for $24 \mathrm{~h}$, the cells were stained with Annexin V-FITC. The numbers indicate the percentages of cells in each fraction.

\section{Results}

FACS analysis revealed that the monoclonal antibody against CD47 designated as mAb-MABL, bound to CD47-L1210, which expressed the human CD47, but not to the vectortransfected L1210 cells (not shown). In addition, mAbMABL induced apoptosis in the hCD47-L1210 cells but not in the vector-transfected L1210 cells as judged by the Annexin$\mathrm{V}$ assay (not shown). The induction of apoptosis was also
A)

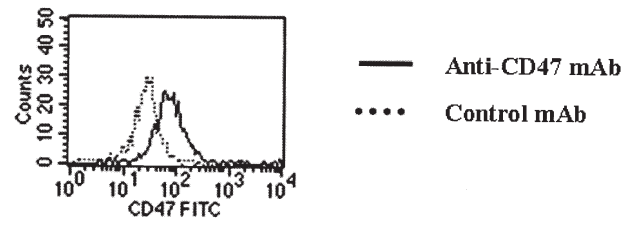

B)
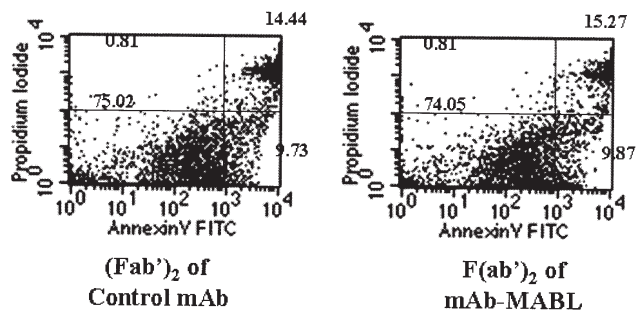

Figure 3. The expression of $\mathrm{CD} 47$ (A) and cell death by $\mathrm{F}\left(\mathrm{ab} \mathrm{b}_{2}\right)_{2}$ of $\mathrm{mAb}-$ MABL (B) in HUVEC cells. (A) Cells were stained with mAb-MABL (antiCD47) together with anti-mouse IgG-FITC, and fluorescences were analyzed with a FACSCalibur. (B) Cells $\left(6 \times 10^{4}\right)$ per well of HUVEC on a 96-well plate were cultured in the presence and absence of $10 \mu \mathrm{g} / \mathrm{ml} \mathrm{F}\left(\mathrm{ab}^{\prime}\right)_{2}$ fragment of mAb-MABL or $10 \mu \mathrm{g} / \mathrm{ml} \mathrm{F}\left(\mathrm{ab}^{\prime}\right)_{2}$ fragment of the control mouse IgG1. After incubation at $37^{\circ} \mathrm{C}$ for $24 \mathrm{~h}$, the cells were stained with Annexin V-FITC. The numbers indicate the percentages of cells in each fraction.

observed in other leukemic cells. CCRF-CEM and JOK-1 cells expressed CD47 antigens and mAb-MABL induced apoptosis in both cells lines within $48 \mathrm{~h}$, as judged by the Annexin-V-FLUOS assay (Fig. 1). We also examined whether $\mathrm{F}\left(\mathrm{ab}^{\prime}\right)_{2}$ of $\mathrm{mAb}-\mathrm{MABL}$ induced cell death against the $\mathrm{CD} 34^{+}$hematopoietic stem/progenitor cells and HUVEC. Although both CD $34^{+}$cord blood cells and HUVEC expressed certain amounts of CD47 on the cell surface, $\mathrm{F}\left(\mathrm{ab} \mathrm{b}_{2}\right)_{2}$ of $\mathrm{mAb}$ MABL did not induce cell death against these cells. The percentages of cell death of $\mathrm{CD} 34^{+}$cord blood cells and HUVEC which occurred in the presence of $F\left(a b^{\prime}\right)_{2}$ of mAbMABL were almost the same as those in the presence of $\mathrm{F}\left(\mathrm{ab}^{\prime}\right)_{2}$ of the control mouse IgG1 (Figs. 2 and 3).

The ability of mAb-MABL to induce the ligation of CD47 and subsequent apoptosis prompted us to examine the antitumor activities of the antibody in vivo. To eliminate the antitumor effects mediated by effectors in vivo, the antitumor activity was examined by administrating the $\mathrm{F}\left(\mathrm{ab}^{\prime}\right)_{2}$ fragment of mAb-MABL into SCID mice implanted with CCRF-CEM or JOK-1 cells. The $\mathrm{F}\left(\mathrm{ab}^{\prime}\right)_{2}$ fragment of mAb-MABL sustained the ability to induce apoptosis in CCRF-CEM and JOK-1 cells in vitro, and apoptosis by $\mathrm{F}\left(\mathrm{ab}^{\prime}\right)_{2}$ of $\mathrm{mAb}-\mathrm{MABL}$ was mediated by $\mathrm{CD} 47$ whereas apoptosis by $\left.\mathrm{F}(\mathrm{ab})_{2}\right)_{2}$ of the control mouse IgG1 was not (Fig. 1).

SCID mice implanted with CCRF-CEM derived from ALL died within 49 days; their mean survival time was 31 days. Administration of $F\left(a b^{\prime}\right)_{2}$ of mAb-MABL twice a day on days 3,4 , and 5 post tumor implantation greatly prolonged the mean survival time. In addition, four out of seven (57\%) mice became tumor-free when they were given $50 \mu \mathrm{g} /$ mouse of the $\mathrm{F}(\mathrm{ab})_{2}$ fragment of mAb-MABL, and all the mice became tumor-free when administrated $200 \mu \mathrm{g} /$ mouse of the $\mathrm{F}\left(\mathrm{ab}^{\prime}\right)_{2}$ fragment (Fig. 4). 


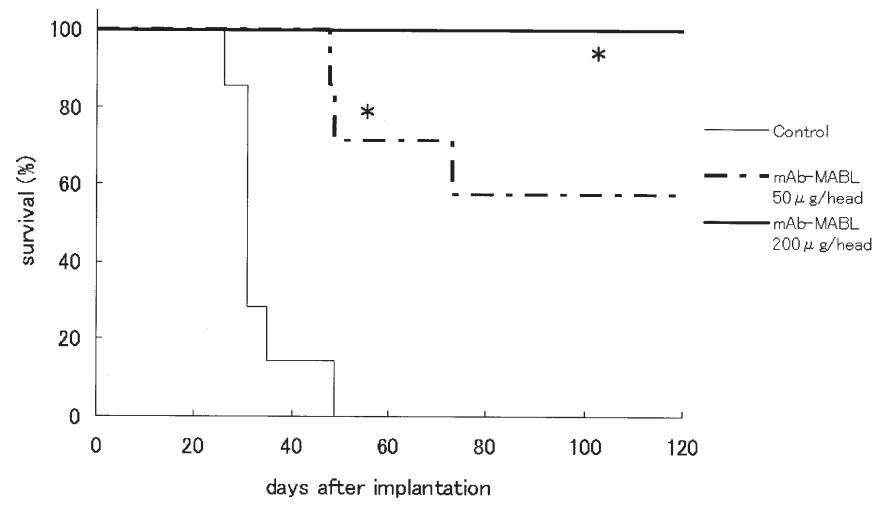

Figure 4. Antitumor activity of the $\mathrm{F}\left(\mathrm{ab}^{\prime}\right)_{2}$ fragment of mAb-MABL in mice implanted with CCRF-CEM. Male SCID mice were intravenously injected with $5 \times 10^{6}$ cells/mouse of CCRF-CEM cells. Thereafter, the mice were intravenously administered PBS (control) or the $\mathrm{F}\left(\mathrm{ab}^{\prime}\right)_{2}$ fragment of $\mathrm{mAb}$ MABL at doses of 0,50 , and $200 \mu \mathrm{g} /$ mouse twice a day ( 7 mice/each group) on days 3,4 , and 5 post tumor implantation. The survival of the mice was monitored daily. ${ }^{*} \mathrm{P}<0.05$ compared with the vehicle administered group (Wilcoxon test).

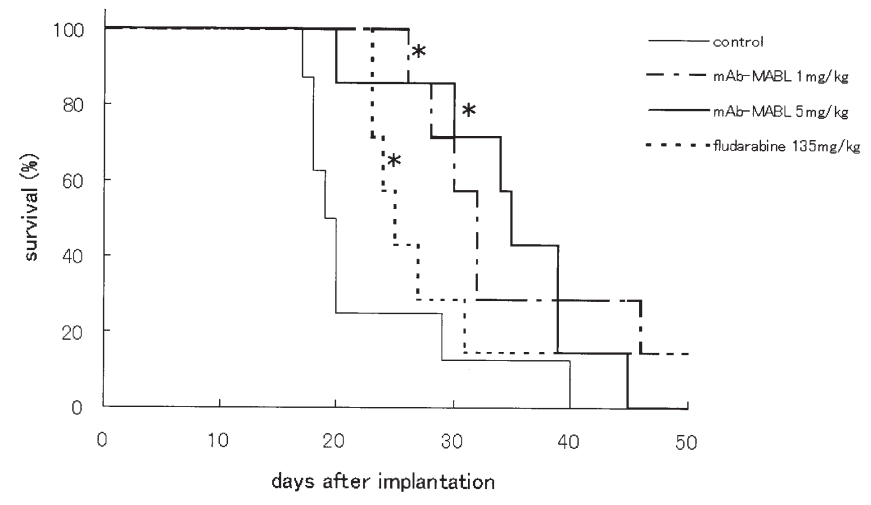

Figure 5. Antitumor activity of the $\mathrm{F}\left(\mathrm{ab}^{\prime}\right)_{2}$ fragment of mAb-MABL in mice transplanted with JOK-1. Male SCID mice were intravenously injected with $5 \times 10^{6}$ cells/mouse of JOK- 1 cells. Thereafter, the mice were intravenously administered PBS (control), F(ab') $)_{2}$ fragment of mAb-MABL at a dose of 1 or $5 \mathrm{mg} / \mathrm{kg}$ twice a day (7 mice/each group) on days 3,4 , and 5 post tumor transplantation, or fludarabine at $135 \mathrm{mg} / \mathrm{kg}$ twice a day for 10 days (from day 3 to day 7 and from day 10 to day 14) post tumor transplantation. Survival of the mice was monitored daily. ${ }^{*} \mathrm{P}<0.05$ compared with the vehicle administered group (Wilcoxon test).

Administration of the $\mathrm{F}\left(\mathrm{ab}^{\prime}\right)_{2}$ fragment of mAb-MABL improved the median survival time in SCID mice intravenously injected with JOK-1 cells originating from B-CLL. The median survival time was 19.5 days in mice given only the vehicle, and 32 and 35 days in mice administered $1 \mathrm{mg} / \mathrm{kg}$ and $5 \mathrm{mg} / \mathrm{kg}$ of the $\mathrm{F}\left(\mathrm{ab}^{\prime}\right)_{2}$ fragment, respectively (Fig. 5). Prolongation of survival by the $\left.\mathrm{F}(\mathrm{ab})_{2}\right)_{2}$ fragment was more pronounced than by fludarabine. When administered intravenously at $135 \mathrm{mg} / \mathrm{kg}$ twice a day for 10 days, fludarabine prolonged the median survival time to 25 days, which was prominently shorter than that achieved by the $\mathrm{F}\left(\mathrm{ab}^{\prime}\right)_{2}$ fragment of mAb-MABL (Fig. 5).

We also examined the antitumor activity of the $F\left(a b^{\prime}\right)_{2}$ fragment of mAb-MABL in mice intraperitoneally injected

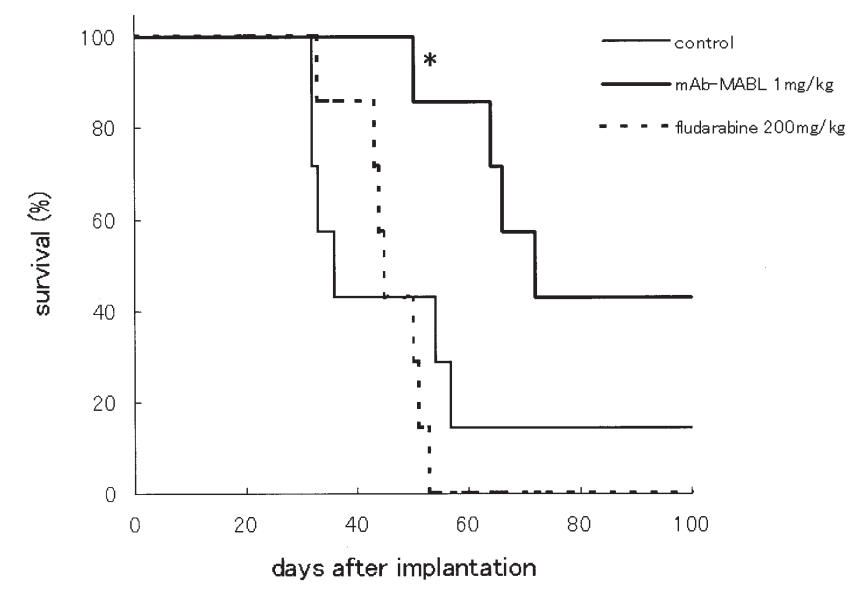

Figure 6. Antitumor activity of the $\left.\mathrm{F}(\mathrm{ab})^{\prime}\right)_{2}$ fragment of mAb-MABL in mice intraperitoneally injected with JOK-1. Male SCID mice were intraperitoneally injected with $2 \times 10^{7}$ cells/mice of JOK-1 cells. Thereafter, the mice were intravenously administered PBS (control) or the $\mathrm{F}\left(\mathrm{ab}^{\prime}\right)_{2}$ fragment of $\mathrm{mAb}-\mathrm{MABL}$ at $1 \mathrm{mg} / \mathrm{kg}$ twice a day (7 mice/each group) on the first 5 days post tumor implantation. Fludarabine was also administered intraperitoneally at a dose of $200 \mathrm{mg} / \mathrm{kg}$ twice a day for 10 days (from day 1 to 5 and from day 15 to 19 ) post tumor implantation. The survival of the mice was monitored daily. ${ }^{*} \mathrm{P}<0.05$ compared with the vehicle administered group (Wilcoxon test).

with JOK-1 cells and compared it to that of fludarabine. Intraperitoneal administration of $200 \mathrm{mg} / \mathrm{kg}$ fludarabine twice a day for 10 days prolonged the survival time. The median survival time was 45 days for mice given fludarabine, whereas it was 36 days in the vehicle-treated mice. At $200 \mathrm{mg} / \mathrm{kg}$ twice a day for 10 days, fludarabine caused severe toxicity as judged by body weight loss. Prolongation of survival was more pronounced when mice were administered the $\left.\mathrm{F}(\mathrm{ab})_{2}\right)_{2}$ fragment of $\mathrm{mAb}-\mathrm{MABL}$. The median survival time increased to 72 days, and 3 out of 7 mice became tumor-free when given $1 \mathrm{mg} / \mathrm{kg}$ of the $\mathrm{F}\left(\mathrm{ab}^{\prime}\right)_{2}$ fragment of mAb-MABL (Fig. 6).

\section{Discussion}

The monoclonal antibody against CD47, mAb-MABL, caused apoptosis in leukemic cell lines possibly by inducing the ligation of $\mathrm{CD} 47$, which raises the possibility that the ligation of CD47 leads to antitumor activity in vivo. To address this possibility, we examined the antitumor activity of the $\mathrm{F}(\mathrm{ab})_{2}$ fragment of mAb-MABL in human leukemia xenograft models. In these models representing ALL and $\mathrm{B}-\mathrm{CLL}$, the $\mathrm{F}\left(\mathrm{ab} \mathrm{b}^{\prime}\right)_{2}$ fragment of mAb-MABL markedly prolonged survival time. In addition, the ligation of CD47 and the subsequent apoptosis of the cells is sufficient to elicit the antitumor activity, as the $\mathrm{F}\left(\mathrm{ab} \mathrm{b}_{2}\right)_{2}$ fragment of mAbMABL does not induce antibody-dependent cell cytotoxicity (ADCC) or complement-dependent cell cytotoxicity (CDC). Thus, the ligation of CD47 and the subsequent induction of apoptosis is a feasible approach to the treatment of leukemic cells.

The mAb-MABL was efficacious against B-CLL cells, Mateo et al (15) reported that the ligation of CD47 induced apoptosis, even when the tumor cells were co-cultured with 
stromal cells. Mice injected intravenously with JOK-1 cells developed paraplegia by day 18 , which is an indication of tumor growth in the bone marrow resulting in the suppression of the spinal cord, and died at a median survival time of 19.5 days. Administration of the $\mathrm{F}\left(\mathrm{ab} \mathrm{b}_{2}\right)_{2}$ fragment of mAb-MABL significantly attenuated the development of paraplegia and prolonged the median survival time. Furthermore, the prolongation of the mean survival time by the $\left.\mathrm{F}(\mathrm{ab})_{2}\right)_{2}$ fragment of mAb-MABL was much more profound than by fludarabine.

SCID mice intraperitoneally injected with JOK-1 also developed lymphadenopathy, splenomegaly, with the appearance of white nodules in the liver, indicative of tumor cell growth in these organs. Intravenous administration of the $\mathrm{F}\left(\mathrm{ab}^{\prime}\right)_{2}$ fragment of mAb-MABL greatly improved the median survival time, and some mice became free of tumor cells. In contrast, fludarabine only slightly prolonged the median survival time even at the dose of $200 \mathrm{mg} / \mathrm{kg}$ twice daily for 10 days, which caused severe toxicity. Together, these results support the possibility that the $\mathrm{F}\left(\mathrm{ab} \mathrm{b}_{2}\right)_{2}$ fragment of mAbMABL kills leukemic cells growing in the bone marrow, lymph nodules, liver, spleen, and in the milieus where leukemic cells are thought to be protected from apoptosis thereby becoming resistant to conventional chemotherapy.

Furthermore, $\mathrm{F}\left(\mathrm{ab}^{\prime}\right)_{2}$ of mAb-MABL did not induce cell death against the $\mathrm{CD} 34^{+}$cord blood cells or HUVEC, although they expressed certain amounts of CD47 on the cell surface. The reason why these cells did not die by the ligation of CD47 is not clear, but the data indicate that the signaling from CD47 is a valuable therapeutic target for the therapy of leukemia.

In conclusion, the $\mathrm{F}\left(\mathrm{ab}^{\prime}\right)_{2}$ fragment of mAb-MABL bound to CD47 and induced apoptosis of leukemic cells possibly by the ligation of CD47. In addition, the $F\left(a b^{\prime}\right)_{2}$ fragment was efficacious against the ALL and B-CLL xenografts without affecting the $\mathrm{CD} 4^{+}$hematopoietic progenitor/stem cells or HUVEC. Thus, mAb-MABL could be developed as a potential therapeutic agent for incurable leukemia after further optimization such as humanization or making single chain diabodies $(28,29)$.

\section{Acknowledgements}

We thank F. Ford of Chugai Pharmaceutical Co., Ltd. for proofreading the manuscript.

\section{References}

1. Smith CA, Farrah T and Goodwin G: The TNF receptor superfamily of cellular and viral protein: Activation, costimulation, and death. Cell 76: 959-962, 1994.

2. Itoh N, Yonehara S, Ishii A, et al: The polypeptide encoded by the cDNA for human cell surface antigen Fas can mediate apoptosis. Cell 66: 233-243, 1991.

3. Ogasawara J, Watanabe-Fukunaga R, Adachi M, et al: Lethal effect of the anti-Fas antibody in mice. Nature 364: 806-809, 1993.

4. Bazil V, Brandt J, Chen S, et al: A monoclonal antibody recognizing CD43 (Leukosialin) initiates apoptosis of human hematopoietic progenitor cells but not stem cells. Blood 87: 1272-1281, 1996.

5. Bazil V, Brandt J, Tsukamoto A and Hoffman R: Apoptosis of human hematopoietic progenitor cells induced by crosslinking of surface CD43, the major sialoglycoprotein of leukocytes. Blood 86: 502-511, 1995.
6. Shan D, Ledbetter JA and Press OW: Apoptosis of malignant human B cells by ligation of CD20 with monoclonal antibodies. Blood 91: 1644-1652, 1998.

7. Pettersen RD, Hestdal K, Olafsen MK, Lie SO and Lindberg FP: CD47 signals T cell death. J Immunol 162: 7031-7040, 1999.

8. Pettersen RD, Bemard G, Olafsen MK, Pourtein M and Lie SO: CD99 signals caspase-independent T cell death. J Immunol 166: 4931-4942, 2001.

9. Skov S, Klausen P and Claesson MH: Ligation of major histocompatability complex (MHC) class I molecules on human $\mathrm{T}$ cells induces cell death through PI-3 kinase-induced c-Jun NH2terminal kinase activity: a novel apoptotic pathway distinct from Fas-induced apoptosis. J Cell Biol 139: 1523-1531, 1997.

10. Mawby WJ, Holmes CH, Anstee DJ, Spring FA and Tanner MJ: Isolation and characterization of CD47 glycoprotein: a multispanning membrane protein which is the same as integrinassociated protein (IAP) and the ovarian tumor marker OA3. Biochem J 304: 525-530, 1994

11. Lindberg FP, Gresham HD, Schwarz E and Brown EJ: Molecular cloning of integrin-associated protein: an immunoglobulin family member with multiple membrane-spanning domains implicated in alpha $\mathrm{v}$ beta 3 -dependent ligand binding. J Cell Biol 123: 485-496, 1993

12. Schwartz MA, Brown EJ and Fazeli B: A 50-kDa integrinassociated protein is required for integrin-regulated calcium entry in endothelial cells. J Biol Chem 268: 19931-19934, 1993.

13. Blystone SD, Lindberg FP, LaFlamme SE and Brown EJ: Integrin beta 3 cytoplasmic tail is necessary and sufficient for regulation of alpha 5 beta 1 phagocytosis by alpha $\mathrm{v}$ beta 3 and integrin-associated protein. J Cell Biol 130: 745-754, 1995.

14. Cooper D, Lindberg FP, Gamble JR, Brown EJ and Vadas MA: Transendothelial migration of neutrophils involves integrinassociated protein (CD47). Proc Natl Acad Sci USA 92: 3978-3982, 1995.

15. Mateo V, Lagneaux L, Bron D, et al: CD47 ligation induces caspase-independent cell death in chronic lymphocytic leukemia. Nat Med 5: 1277-1284, 1999.

16. Mateo V, Brown EJ, Biron G, et al: Mechanisms of CD47induced caspase-independent cell death in normal and leukemic cells: link between phosphatidylserine exposure and cytoskeleton organization. Blood 100: 2882-2890, 2002.

17. Lamy L, Ticchioni M, Rouquette-Jazdanian AK, et al: CD47 and $19 \mathrm{kDa}$ interacting protein-3 (BNIP3) in T cell apoptosis. J Biol Chem 26: 23915-23921, 2003.

18. Manna PP and Frazier WA: CD47 mediates killing of breast tumor cells via Gi-dependent inhibition of protein kinase A. Cancer Res 64: 1026-1036, 2004.

19. Johansson U, Higginbottom K and Londei M: CD47 ligation induces a rapid caspase-independent apoptosis-like cell death in human monocytes and dendritic cells. Scand J Immunol 59: 40-49, 2004.

20. Graf R, Freyberg M, Kaiser D and Friedl P: Mechanosensitive induction of apoptosis in fibroblasts is regulated by thrombospondin-1 and integrin associated protein (CD47). Apoptosis 7: 493-498, 2002.

21. Cheson BD, Bennett JM, Grever M, et al: National Cancer Institute-sponsored Working Group guidelines for chronic lymphocytic leukemia: revised guidelines for diagnosis and treatment. Blood 15: 4990-4997, 1996.

22. Dighiero G, Maloum K, Desablens B, et al: Chlorambucil in indolent chronic lymphocytic leukemia. French Cooperative Group on Chronic Lymphocytic Leukemia. N Engl J Med 338: $1506-1514,1998$

23. Keating MJ, O'Brien S, Lerner S, et al: Long-term follow-up of patients with chronic lymphocytic leukemia (CLL) receiving fludarabine regimens as initial therapy. Blood 92: 1165-1171, 1998.

24. De la Fuente MT, Casanova B, Garcia-Gila M, Silva A and Garcia-Pardo A: Fibronectin interaction with alpha4beta1 integrin prevents apoptosis in B cell chronic lymphocytic leukemia: correlation with Bcl-2 and Bax. Leukemia 13: 266-274, 1999.

25. Hosler GA, Bash R and Scheuermann RH: Kinetics of early therapeutic response as measured by quantitative PCR predicts survival in a murine xenograft model of human $\mathrm{T}$ cell acute lymphoblastic leukemia. Leukemia 14: 1215-1224, 2000.

26. Bai L, Kon K, Tatsumi M, Ito H, Hayashi S and Brautigam M: A human B-cell CLL model established by transplantation of JOK-1 cells into SCID mice and anti-leukemia efficacy of fludarabine phosphate. Oncol Rep 7: 33-38, 2000. 
27. Kontula K, Paavonen T, Vuopio P and Andersson LC: Glucocorticoid receptors in hairy-cell leukemia. Int J Cancer 30: 423-426, 1982.

28. Kikuchi Y, Uno S, Yoshimura Y, et al: A bivalent single-chain Fv fragment against CD47 induces apoptosis for leukemic cells. Biochem Biophys Res Commun 315: 912-918, 2004.

29. Kikuchi Y, Uno S, Kinoshita Y, et al: Apoptosis inducing bivalent single-chain antibody fragments against CD47 showed antitumor potency for multiple myeloma. Leuk Res 29: 445-450, 2005.
30. Shulman M, Wilde CD and Köhler G: A better cell line for making hybridomas secreting specific antibodies. Nature 276 : 269-270, 1978.

31. Galfre G and Milstein C: Preparation of monoclonal antibodies: strategies and procedures. Methods Enzymol 73: 3-46, 1981.

32. Martin SJ, Reutelingsperger CPM, McGahon AJ, et al: Early redistribution of plasma membrane phosphatidylserine is a general feature of apoptosis regardless of the initiating stimulus: Inhibition by overexpression of Bcl-2 and Abl. J Exp Med 182: 1545-1556, 1995. 